\title{
RASISME DALAM KEPEMIMPINAN DI INDONESIA (Perspektif Hadis)
}

\author{
Nor Istiqomah \\ Universitas Islam Negeri Sunan Kalijaga Yogyakarta \\ istiqomah999@gmail.com
}

Diterima 26 Maret 2018 | Direview 09 September 2018 | Diterbitkan 15 Oktober 2018

\begin{abstract}
:
Cases of racism have occurred in the early days of the emergence of Islam, which later became the political legitimacy in which in the leadership space in the Arabian Peninsula the tribe of Quraish is a tribe that dominates. This is reinforced by the argument of hadith which became the basis of that legitimacy. Nonetheless, in fact there are many other propositions that seem quite contrary to the proposition, such as the Qur'an and other hadith. Therefore, the hadith about political racism which in this case about the domination of tribal leadership of Quraish becomes important to be reinterpreted by using hermeneutic point of view and contextualization of hadith. With this view, the election of a leader is not based on a particular tribe, although assessing of the leadership qualities of the future leader as well as his responsibility in carrying out the mandate of the leader. In the context of Indonesian, the dominance of a tribe in political space is controlled by the political interest of various circles, such as political elites and radical groups. The view that political domination held by a particular group is only used as a "scapegoat" to overthrow the political opponents.
\end{abstract}

Keywords: Leadership, Racism, Hermeneutics, Hadith.

\begin{abstract}
Abstrak:
Kasus-kasus rasisme telah terjadi pada masa-masa awal munculnya Islam, yang kemudian menjadi legitimasi politik di mana di ruang kepemimpinan di Semenanjung Arab suku Quraisy adalah suku yang mendominasi. Ini diperkuat oleh argumen hadits yang menjadi dasar legitimasi itu. Meskipun demikian, sebenarnya ada banyak proposisi lain yang tampaknya bertentangan dengan proposisi, seperti Al-Quran dan hadis lainnya. Oleh karena itu, hadits tentang rasisme politik yang dalam hal ini tentang dominasi kepemimpinan suku Quraish menjadi penting untuk ditafsirkan ulang dengan menggunakan sudut pandang hermeneutik dan kontekstualisasi hadits. Dengan pandangan ini, pemilihan pemimpin tidak didasarkan pada suku tertentu, meskipun menilai kualitas kepemimpinan pemimpin masa depan serta tanggung jawabnya dalam melaksanakan mandat pemimpin. Dalam konteks Indonesia, dominasi suku di ruang politik dikendalikan oleh kepentingan politik berbagai kalangan, seperti elit politik dan kelompok radikal. Pandangan bahwa dominasi politik yang dipegang oleh kelompok tertentu hanya digunakan sebagai "kambing hitam" untuk menggulingkan lawan-lawan politik.
\end{abstract}

Kata Kunci: Kepemimpinan, Rasisme, Hermeneutika, Hadis.

\section{Pendahuluan}

Di Indonesia, diskriminasi terhadap kelompok minoritas sering terjadi. Kasus rasisme misalnya, terutama pada kelompok minoritas ras China sudah bukan menjadi topik baru. Perlakuan rasisme terhadap kelompok ini telah terjadi jauh pada masa kolonial Belanda. Namun, tindakan rasisme kembali terjadi pada akhir-akhir ini. Rasisme pada masa ini tidak hanya mempermasalahkan sejarah ekonomi dan sosial bangsa ini, tetapi lebih berkembang dan diungkit-ungkit, terutama dalam ruang politik.

Bukan menjadi berita lama bahwa masa-masa politik negara merupakan masa-masa yang genting dan sensitif. Apapun akan dihalalkan untuk mendapatkan posisi strategis dalam politik. Tidak peduli apakah itu masalah sosial, rasisme, etnisisme, ekonomi, bahkan permasalahan agama akan ditarik dalam memenangkan politik. Yang cukup mengkhawatirkan adalah bahwa dampak perebutan tempat politis tersebut berujung pada kasus SARA yang melibatkan massa dari berbagai kalangan.

Pemilihan umum calon gubernur ibu kota Jakarta pada tahun 2012 dapat disoroti. Salah satu pasangan cagub dan cawagub, yaitu Joko Widodo dan Basuki Tjahaja Purnama misalnya. Sudah diketahui oleh publik bahwa cawagub Basuki Tjahaja Purnama "Ahok" merupakan seorang yang berdarah Tionghoa. Kasus diskriminasi ras China kembali diungkit. Mereka lalu mendapat tuduhan dari berbagai kalangan bahwa ras China tidak pantas memimpin ibu kota Jakarta tersebut. Beruntung kasus tersebut dapat diusut dengan baik 
oleh pasangan cagub-cawagub tersebut dengan membentuk tim khusus bernama Jasmev yang bertujuan menghadang isu negatif. ${ }^{1}$

Setelah berhasil menjadi gubernur DKI Jakarta, Joko Widodo naik mengikuti pemilihan umum presiden pada tahun 2014 dengan pasangan Jokowi-JK. Kembali Jokowi mendapat isu negatif. Dari beberapa laman berita media masa disebutkan bahwa ia dituduh memiliki garis keturunan Tionghoa. Hingga dalam masa pemerintahannya, Jokowi masih mendapat tuduhan serupa. Hal ini disebabkan menurut para pengamat ekonomi, ekonomi yang dijalankan pada masa Jokowi cenderung pada Tiongkok, sehingga muncul sentimen bahwa Jokowi seorang Komunis. Padahal, ekonomi yang dijalankan lebih bersifat neoliberalkapitalistik. $^{2}$

Kasus serupa juga terjadi pada wakil gubernurnya yang kemudian naik menjadi gubernur DKI Jakarta sejak November 2014 hingga bulan Mei 2017. Kasus yang terjadi pada Ahok cukup rumit, awalnya Ahok mendapat tuduhan melakukan penistaan agama. Namun kemudian, banyak perihal yang disangkut-pautkan dalam melawan politiknya. Termasuk salah satunya tuduhan rasisme. Kasus diskriminasi ras Tionghoa kembali terjadi. Walaupun kemudian kebencian para lawan politik Ahok terkait penistaan agama menjadi tolak ukur utama kegagalan politik Ahok dalam pemilihan umum gubernur selanjutnya. ${ }^{3}$

Ketakutan para masyarakat terhadap ras Tionghoa tidak lain karena peristiwa yang terjadi pada masa lalu. Hingga permasalahan tersebut kini dibawa pada ranah politik. Kasus yang dialami Jokowi dan Ahok menjadi salah satu contoh diskriminasi yang masih berlaku pada dekade ini. Namun, kasus ini menjadi kuat dengan adanya pengaruh kuat politik yang menjadi pusat utama pembicaraan di mana-mana. Yang membawa kesan bahwa pemimpin di indonesia seolah-olah harus orang asli indonesia, harus dari suku-suku indonesia, tanpa ada darah campuran maupun darah asli warga negara asing.

Jika ditarik ulur ke belakang, kasus rasis pernah terjadi pada masa Islam awal yang mengharuskan pemerintahan dikendalikan oleh suku Quraisy pada era Nabi hingga beberapa masa imperium kekaisaran Muslim, seperti dinasti Umayyah dan Abbasiyah. Lalu, muncul hadis yang mengintervensi kasus pemerintahan Quraisy yang dianggap sebagai dalil kuat untuk mempertahankan dominasi Quraisy sebagai suku tertentu di jazirah Arab dalam ruang politik. Tulisan ini akan mengkaji ulang hadis yang diasumsikan mengandung rasis dalam ruang politik.

\section{Perspektif Hadis}

Dalam kajian hadis yang dapat mendukung kajian isu-isu aktual tersebut ialah dengan menggunakan studi ma'anil hadis. Dalam penerapan ma'anil hadis, para pemikir hadis kontemporer terbagi dalam tiga bagian; pertama, studi yang bertumpu pada otoritas teks; kedua, studi yang memprioritaskan horizon pembaca; dan ketiga, menyeimbangkan dialog antara teks, pembaca dan konteks (triodik hermeneutika). Kajian berikut akan menggunakan metode ketiga, yaitu melihat keseimbangan antara teks, pembaca dan konteks untuk mendapatkan pemahaman yang lebih kontekstual.

Adapun hadis yang akan dikaji ialah hadis yang terkait dengan adanya rasisme yang bersentuhan dengan ruang politik, yaitu hadis-hadis yang terkait kepemimpinan, yang dalam hal ini melihat kepemimpinan pada mana Nabi yang ditujukan pada suku tertentu, yaitu suku Quraisy. Adapun hadis-hadis tersebut ialah sebagai berikut: hadis al-Bukhari no. 3.369:

${ }^{1}$ Iqbal Fadil, "4 Pengakuan JASMEV, pasukan Jokowi di media sosial” diakses tanggal 1 Januari 2018 dalam https://www.merdeka.com

2Leo Suryadinata, "Anti-China campaign in Jokowi's Indonesia" diakses tanggal 1 Januari 2018 dalam http://www.straitstimes.com

${ }^{3}$ Safari dan Akbar, "Kasus Ahok: Pertempuran China Pro Jokowi dan Amerika Pro SBY" diakses tanggal 1 Januari 2018 dalam http://nasional.harianterbit.com 


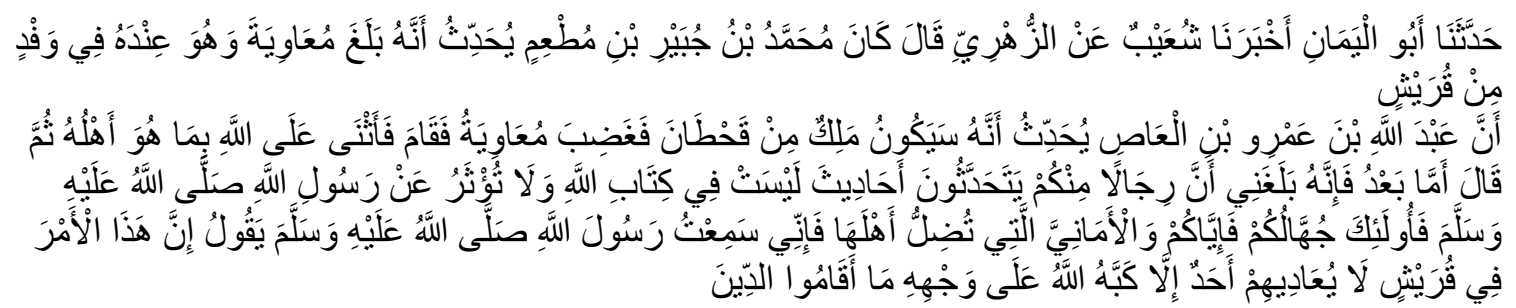

(Bukhari - 3.369) : Telah bercerita kepada kami Abu al-Yaman, telah mengabarkan kepada kami Syu'aib dari az-Zuhriy berkata; Muhammad bin Jubair bin Muth'im pernah bercerita kepadanya bahwa ada berita yang sampai kepada Mu'awiyah yang saat itu dia sedang mempunyai urusan dengan orang Quraisy bahwa 'Abdullah bin 'Amru bin al-'Ash menceritakan bahwa akan ada raja dari kalangan suku Qahthan (di Yaman). Mu'awiyah kemudian marah lalu berdiri kemudian memuji Allah Ta'ala dan segala pengagungan yang memang hanya patut bagi-Nya kemudian berpidato; "Hadirin yang dimuliakan. Sungguh telah sampai kepadaku orang-orang dari kalian yang menyampaikan pembicaraan yang tidak ada dalam Kitab Allah dan juga bukan dinukil dari sabda Rasulullah Shallallahu 'alaihi wa salam. Mereka itulah orang-orang bodoh dari kalian. Oleh karena itu kalian harus waspada terhadap angan-angan yang menyesatkan para pelakunya. Sungguh aku pernah mendengar Rasulullah Shallallahu 'alaihi wa salam bersabda: "Sesungguhnya urusan (khilafah/pemerintahan) ini berada pada suku Quraisy dan tidak ada seorangpun yang menentang mereka melainkan Allah Ta'ala pasti akan menelungkupkan wajahnya ke tanah selama mereka (Quraisy) menegakkan ad-din (agama)". 4

Hadis riwayat al-Bukhari no. 6.720:

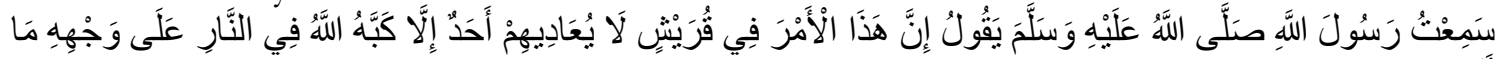

(Bukhari - 6.720) : .... Rasulullah shallallahu 'alaihi wasallam bersabda: "Kepemimpinan ini tetap berada di quraisy, tidaklah seseorang memusuhi mereka, selain Allah menelungkupkannya dalam neraka diatas wajahnya, selama mereka menegakkan agama." 5

Hadis riwayat Ahmad no. 17.315:

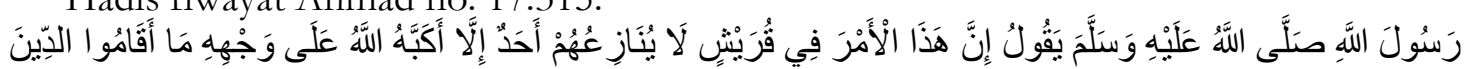

(Ahmad - 17.315) : Rasulullah Shallallahu'alaihiwasallam bersabda: "Sesungguhnya urusan kepemimpinan akan tetap berada pada tangan orang Quraisy. Tidak ada seorang pun yang mencabutnya kecuali Allah Azzawajalla akan menelungkupkan wajahnya selama mereka menegakkan agama."

Hadis riwayat Ahmad no. 12.641:

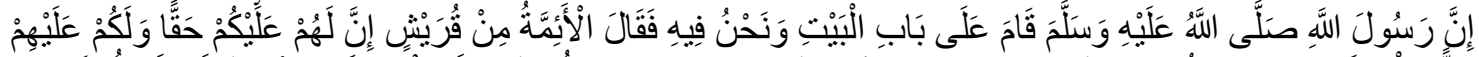

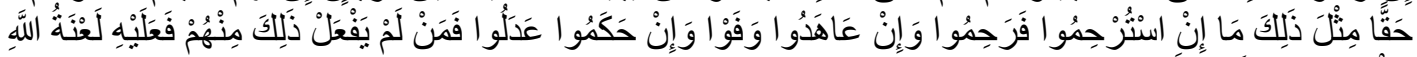

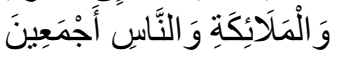

(Ahmad - 12.641) : .... sesungguhnya Rasulullah shallallahu 'alaihi wasallam pernah berdiri di depan pintu, sedang kami ada di situ, beliau lalu bersabda: "Sesungguhnya pemimpin itu dari Quraisy, mereka punya hak yang harus kalian penuhi sebagaimana kalian juga mempunyai hak yang harus mereka penuhi. Jika diminta untuk mengasihi, mereka akan mengasihi, jika membuat janji mereka penuhi, jika menetapkan hukum mereka berlaku adil.

${ }^{4}$ Hadis riwayat al-Bukhari no. 3.369, Bab Manaqib Quraisy, "Kitab al-Manaqib", Muhammad bin Ismail Abu 'Abdillah al-Bukhari, Al-Jami' al-Shabih al-Mukhtashar, vol. 3 (Beirut: Dar Ibn Katsir, 1987), h. 1.289.

${ }^{5}$ Hadis riwayat al-Bukhari no. 6.720, Bab al-Umara' min Quraisy, "Kitab al-Ahkam”, Al-Bukhari, Al-Jami' ..., vol. 6, h. 2.611.

${ }^{6}$ Hadis riwayat Ahmad no. 17.315, Bab Hadis Mu'awiyab bin Abi Sufyan, Abu 'Abdillah Ahmad bin Muhammad bin Hanbal bin Hilal bin Asad al-Syaibani, Musnad Abmad, vol. 36 (Ttp: Mauqi' Wizarah al-Auqaf al-Mishriyyah, Tt.), h. 258. 
Maka barangsiapa dari mereka yang tidak melakukan seperti itu, mereka akan mendapatkan laknat Allah, malaikat dan semua manusia.",

Hadis riwayat Ahmad no. 13.238:

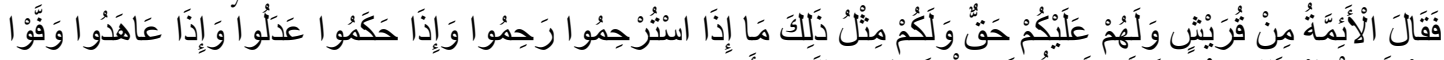

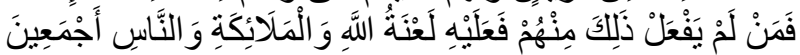

(Ahmad - 13.238) : “.... Para pemimpin itu dari Quraisy, mereka mempunyai hak atas kalian dan juga sebaliknya, jika mereka dimohon bersikap sayang maka mereka menyayangi, jika menghukum maka mereka lakukan dengan adil, jika berjanji memenuhinya, dan jika mereka tidak melakukannya maka mereka mendapat laknat Allah, malaikat dan manusia semuanya."

Hadis riwayat Ahmad no. 20.308:

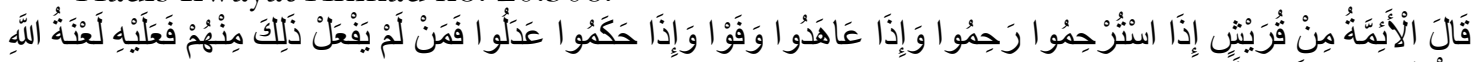

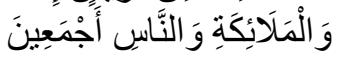

(Ahmad - 20.308) .... "Pemimpin itu dari bangsa Quraisy, karena apabila mereka dimintakan untuk menyayangi, maka mereka akan menyayangi, apabila mereka mengadakan perjanjian maka mereka akan menepatinya, apabila mereka menetapkan hukum, maka mereka akan berbuat adil. Dan barangsiapa yang tidak melaksanakan hal tersebut diantara mereka, maka baginya akan mendapat laknat dari Allah, malaikat dan manusia seluruhnya."9

Hadis riwayat al-Darimi no. 2.576:

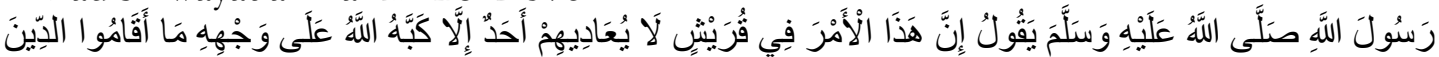

(Darimi - 2.576) : .... Rasulullah shallallahu 'alaihi wasallam bersabda: "Sesungguhnya perkara kekhilafahan ini ada pada orang-orang Quraisy, tidak ada seorangpun yang menentang mereka kecuali Allah akan menghinakannya selama mereka menegakkan agama ini." 10

Jalur 1, riwayat al-Bukhari no. 3.369, 6.720 dan riwayat al-Darimi no. 2.576 yang terdapat 6 orang periwayat, yaitu (1) Mu'awiyah bin Abi Sufyan, diakui ke'adalahannya (2) Muhammad bin Jubair bin Muth'im bin 'Adiy, dinilai tsiqah (3) Muhammad bin Muslim bin 'Ubaidillah bin 'Abdullah bin Syihab, dinilai faqib hafidz (4) Syu'aib bin Abi Hamzah, dinilai tsiqah (5) Al-Hakam bin Nafi', dinilai tsiqah (6) al-Bukhari dinilai ahfadz al-badis.

Jalur 2, riwayat Ahmad no. 17.315, terdapat 6 orang periwayat yang lima orang di antaranya sama dengan periwayat jalur 1 , yaitu periwayat no 1, 2, 3, 4, dan 6. Sedangkan periwayat ke-5 ialah Bisyr bin Syu'aib bin Abi Hamzah, yang dinilai tsiqah.

Jalur 3, riwayat Ahmad no. 12.641, terdapat 6 periwayat yang terdiri atas (1) Anas bin Malik, diakui ke'adalahannya (2) Bukair bin Wahab, dinilai maqbul dan laisa bi qowiy (3) Sahal, dinilai maqbul (4) Syu'bah bin al-Hajjaj bin al-Warad, dianggap sebagai amir al-mukminin fi alhadis (5) Muhammad bin Ja'far, dinilai tsiqah (6) Ahmad bin Hanbal, dinilai shadaqa hadisuh.

Jalur 4, riwayat Ahmad no. 13.238, terdapat 6 orang periwayat yang empat di antaranya periwayat yang sama di jalur 3, yaitu periwayat no. 1, 2,3 dan 6. Sedangkan periwayat 4 dan 5 berbeda, Sulaiman bin Mihran yang dinilai tsiqah sabat dan Waki' bin alJarrah bin Malih yang dinilai seorang yang tsiqah dan bafid\%:

Jalur 5, riwayat Ahmad no. 20.308, terdapat 5 orang periwayat, yang terdiri atas (1) Nadhlah bin 'Ubaid, diakui ke'adalabannya (2) Sayyar bin Salamah, dinilai tsiqab (3) Sukain

${ }^{7}$ Hadis riwayat Ahmad no. 12.641, Bab Musnad Anas Bin Malik, Ahmad al-Syaibani, Musnad Ahmad, vol. 26, h. 174.

${ }^{8}$ Hadis riwayat Ahmad no. 13.238, Bab Musnad Anas Bin Malik, Ahmad al-Syaibani, Musnad Ahmad, vol. 27, h. 271

${ }^{9}$ Hadis riwayat Ahmad no. 20.308, Bab Hadis Abi Barzah al-Aslami, Ahmad al-Syaibani, Musnad Ahmad, vol. 43 , h. 109.

${ }^{10}$ Hadis riwayat al-Darimi no. 2.576, Bab al-Imarah fi Quraisy, "Kitab al-Yasir", 'Abdullah bin 'Abd alRahman bin al-Fadhl bin Bahram al-Darimi, Sunan al-Darimi, vol. 8 (Ttp: Mauqi' Wizarah al-Auqaf alMishriyyah, Tt.), h. 50. 
bin 'Abd al-'Aziz bin Qais, dinilai la ba'sa bih (4) Sulaiman bin Daud bin al-Jarud, dinilai tsiqah shaduq (5) Ahmad bin Hanbal dinilai shadaqa hadisuh.

Secara ringkas, penilaian otentisitas hadis dari aspek sanad yang dinilai dari persambungan sanad hadis-hadis dapat dikatakan muttashil (bersambung sanadnya) dan marfu' (sanad yang terhubung hingga ke Nabi). Hal tersebut dapat dilihat dari kesezamanan antar periwayat, hubungan guru dan murid, serta shigah tahammul wa al-ada' (perangkat periwayatan) yang dipergunakan. Dengan mempertimbangkan aspek-aspek tersebut, maka kualitas sanad hadis di atas dapat dipegangi bersumber dari Nabi.

\section{Aspek Bahasa}

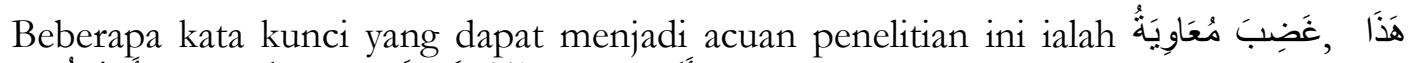

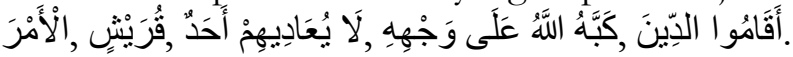

Gadbiba Mu'awiyah diartikan dengan Mu'awiyah yang marah, hadza al-amr diartikan khilafah/pemerintahan, Quraisy diartikan suku Quraisy, la yu'adibim abadun diartikan tidak seorangpun yang menentang mereka, kabbabullah 'ala wajbibi diamaknai Allah menelungkupkan wajahnya ke tanah, dan aqam al-din diartikan menegakkan din (agama).

Terdapat perbedaan redaksi matan hadis utama dengan hadis pendukung. Narasi yang terdapat dalam hadis utama didukung oleh hadis Bukhari lainnya no. 6.720 dan Ahmad no. 17.315, sedangkan pada riwayat al-Darimi no. 2.576 narasi dipaparkan secara singkat dengan mengutamakan inti matan yang disampaikan Nabi saw. Perbedaan matan hadis yang sangat jelas terlihat ialah penggunaan redaksi dalam hadis riwayat Bukhari no. 3.369 dan riwayat Ahmad no. 17.315 yang dalam narasinya menyebutkan dengan jelas genealogi 'Abdullah bin 'Amr bin 'Ash, padahal redaksi yang digunakan dalam hadis pendukung yaitu riwayat Bukhari no. 6.720 tidak menyebutkan demikian. Demikian pula dengan penggunaan redaksi yatabaddatsun ahadis dalam hadis utama berbeda dengan hadis pendukung yang lebih menggunakan redaksi yuhadditsun. Begitu juga dengan kabbahullah 'ala wajhih, dalam riwayat al-Bukhari no. 6.720 diriwayatkan dengan tambahan $f i$ al-nar, yaitu kabbabullah fi al-nar 'ala wajhih. Dalam riwayat Ahmad no. 17.315, penggunaan kata la yu'adibim diganti menjadi la yunazi ubum dan kabbabullah menjadi akabbabullah. Sedangkan dalam riwayat al-Darimi, walaupun narasi hadis diriwayatkan secara singkat, redaksi matan hadis yang digunakan hampir sepenuhnya mengikuti redaksi matan hadis utama.

Adapun hadis lain yang diriwayatkan oleh Ahmad no. 12.641, 13.238 dan 20.308 merupakan hadis yang memiliki perbedaan matan. Hadis no. 12.641 memiliki kesamaan dengan no. 20.308, walaupun hadis no. 20.308 tersebut tanpa disertai kalimat inna labum 'alaikum haqqan wa lakum 'alaibim haqqan mitslu dzalika. Sedangkan pada hadis no. 13.238 menyebutkan matan wa lahum 'alaikum haqq wa lakum mitslu dzalika serta kalimat idza hakamu 'addalu yang mengalami perbalikan kalimat dengan dua hadis lainnya. Ketiga hadis tersebut memiliki matan yang sama yang berisi tentang suatu kepemimpinan yang hanya dimiliki oleh suku Quraisy, dengan menyebutkan sifat-sifat ornag Quraisy jika memimpin, yaitu yang jika diminta untuk menyayangi, maka mereka akan menyayangi, jika mengadakan perjanjian maka mereka akan menepatinya, dan jika menetapkan hukum, maka mereka akan berbuat adil. Matan selanjutnya berisi tentang peringatan. Tetapi, terjadi perbedaan objeknya, di mana empat hadis sebelumnya peringatan pada orang-orang yang tidak mematuhi kepemimpinan Quraisy, sedangkan pada tiga hadis berikutnya peringatan yang ditujukan bagi pemimpin-pemimpin dari suku Quraisy.

Kepemimpinan suku Quraisy dianggap lebih shahih, sehingga bagi yang menentang hal tersebut akan ditimpa masalah, yaitu kabbabullah 'ala wajbih. Menurut Ibn Asyur, kata Kabba dapat berarti inqalaba (dibalik/diputar), yang dalam konteks ini merupakan kalimat majaz. Pasalnya, kata inqalaba memiliki konteks yang jelas jika disandingkan dengan frase 'ala 'aqibaih (ke belakang), tidak demikian halnya jika disandingkan dengan frase 'ala wajhih (dengan wajahnya). Ibn 'Asyur juga mengemukakan makna lain dari inqalaba yang berarti 
syirik. Dampak dari inqalaba 'ala wajbih dapat meliputi kerugian di dunia dan akhirat. ${ }^{11}$ Kata kabbahullah menurut Al-Bukhari lebih condong dengan penghinaan Allah, penelantaraanNya terhadap hamba-Nya yang durhaka serta melemparnya ke neraka dengan keadaan terbalik. ${ }^{12}$ Mengamini pendapat al-Bukhari, Ibn Hajar menyatakan bahwa kabbabullab dengan mempertimbangkan kalimat sebelumnya, yaitu la yu'adibim abad, maka dapat dimaknai bahwa yang menentang pemerintahan suku Quraisy dapat berkuasa di dunia tetapi akan mendapat siksaan di akhirat kelak. ${ }^{13}$ Demikian pula al-Thayalisi, al-Baihaqi, al-Thabrani dan alAshbahani sepakat bahwa kabbahu bermakna menelungkupkannya/menjungkir-balikkannya dan melemparkannya dengan mendahulukan wajahnya.

Dengan demikian, dapat disimpulkan bahwa kalimat kabbabullab 'ala wajhih merupakan kalimat majaz yang terdapat pada hadis tersebut. Makna yang diambil oleh kebanyakan ulama ialah konsekuensi yang diterima seseorang jika menentang suatu pemerintahan yang dalam konteks ini pemerintahan suku Quraisy di jazirah arab, yaitu dengan mendapat balasan siksaan yang dipahami akan terjadi di dunia dan di akhirat.

\section{Aspek Historis}

Hadis tersebut dikeluarkan kembali oleh Mu'awiyah sebagai respons yang pada saat tersebut tidak menyetujui apa yang dikemukakan oleh 'Abdullah bin 'Amr bin 'Ash yang mengaku akan menjadi raja di Qahthan (suku di Yaman/suku Himyar), menurut Mu'awiyah tidak berdasarkan pada apa yang disampaikan Nabi bahwa pemerintahan di jazirah arab saat itu hanya layak dipimpin oleh suku Quraisy. Menurut Ibn Hajar, kasus serupa pernah terjadi pada peristiwa Saqifah Bani Sa'idah dalam pembaiatan Abu Bakar. Di mana dalam

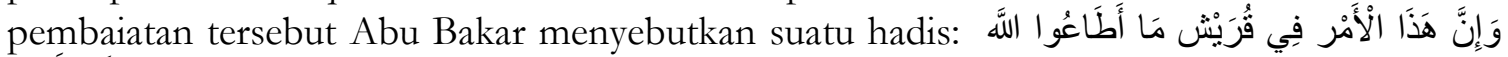
yang kemudian dari peristiwa tersebut, Abu Bakar mengemukakan tiga hal terkait pemerintahan suku Quraisy:

1. Mereka akan dilaknat jika tidak menjaga amanat yang diberikan.

2. Mereka memiliki otoritas terhadap gangguan-gangguan.

3. Mereka wajib melakukan perizinan untuk mendirikan bangunan, melakukan peperangan bahkan perizinan juga dilakukan untuk keluar dari urusan-urusan mereka sendiri. ${ }^{14}$

Beberapa hal yang memunculkan hadis tersebut ialah pertama, suku Quraisy dianggap memiliki kemampuan dalam memimpin dibandingkan suku lain; kedua, dalam beberapa dekade pemerintahan dipimpin oleh para khalifah yang berasal dari suku Quraisy; ketiga, turunnya al-Qur'an dengan ruang dan waktu di Mekah-Madinah dengan audience utama suku Quraisy dan bahkan penggunaan bahasa wahyu yang digunakan adalah bahasa Arab Quraisy $^{15}$, menjadi tolak ukur bahwa kemungkinan pemahaman mereka menjadi lebih dekat (lebih memahami kandungan wahyu dan kedekatan mereka dengan Nabi sebagai central figure) sehingga membutuhkan pemimpin dari golongan Quraisy sendiri; keempat, perkembangan jazirah arab kala itu cukup pesat dan maju dalam bidang bahasa dan perdagangan misalnya, yang saat itu dikuasai oleh suku Quraisy.

\section{Kajian Tematik}

a. Beberapa kasus pemimpin

Pada masa Nabi, kepemimpinan sangat beragam, di antaranya:

1) Pemimpin dari suku-suku yang lain

\footnotetext{
${ }^{11}$ Ibn 'Asyur, al-Tahrir wa al-Tanwir, vol. 9 (Mauqi' al-Tafassir, tt. ), h. 243.

${ }^{12} \mathrm{Al}-\mathrm{Bukhari,}$ al-Jami' al-Shabih al-Mukhtashar, vol. 3, h. 1.289.

${ }^{13}$ Ibn Hajar al-Asqalani, Fath al-Bari Syarh Shahih al-Bukhari (Beirut: Dar al-Ma'rifah, 1379 H), Jilid 6, h.

${ }^{14} \mathrm{Ibn}$ Hajar, Fath al-Bari, vol. 6, h. 636.

${ }^{15}$ Ibn Katsir, Tafsir al-Qur'an al-'Adzim, vol. 7 (Beirut: Dar Thaibah li al-Nasyr wa al-Tauzi', 1999), h.
} 635. 
Nabi pernah menyuruh seorang dari kaum Anshar (tidak dijelaskan apakah berasal dari suku Auz atau Khazraj) sebagai pemimpin. Akan tetapi, kasus itu menunjukkan bahwa kepemimpinan itu boleh ditaati hanya dalam tataran kebajikan. Ini menggambarkan kasus di mana pemimpin tidak harus berasal dari suku tertentu, tetapi ditimbang dari apa yang pemimpin itu perintahkan. Yang melatari kasus tersebut ialah riwayat Muslim no. 1.840 sebagai berikut:

(Muslim - 1.840) : .... "Rasulullah shallallahu 'alaihi wasallam pernah mengutus suatu ekspedisi dan mengangkat seorang laki-laki dari Anshar sebagai pemimpinnya, mereka diperintahkan untuk taat dan mendengar kepadanya, suatu ketika pemimpinnya marah terhadap anak buahnya karena suatu perkara, dia berkata, "Kumpulkanlah kayu bakar." Setelah kayu bakar terkumpul dia berkata, "Bukankah Rasulullah shallallahu 'alaihi wasallam telah memerintahkan kepada kalian untuk mendengarkanku dan mentaatiku?" mereka menjawab, "Ya." Dia berkata, "Oleh karena itu, masuklah kalian ke dalam api tersebut." Ali berkata, "Lalu sebagian yang lain saling memandang kepada yang lainnya, sambil berkata, "Kita harus lari kepada Rasulullah shallallahu 'alaihi wasallam dari api tersebut." Anak buahnya masih saja (dalam kebimbangan) seperti itu, hingga kemarahannya mereda dan api dimatikan. Ketika mereka kembali, mereka memberitahukan peristiwa itu kepada Nabi shallallahu 'alaihi wasallam, lalu beliau bersabda: "Sekiranya kalian masuk ke dalamnya, niscaya kalian tidak akan dapat keluar dari api tersebut, ketaatan itu hanya dalam kebajikan" ${ }^{16 .}{ }^{16}$

2) Pemimpin dari budak

Perintah Nabi untuk menaati seorang budak yang menjadi pemimpin menunjukkan bahwa seorang pemimpin tidak diukur oleh faktor kultur dan budaya yang berasal dari suku tertentu. Hal ini dapat ditemukan dalam riwayat berikut:

(Muslim - 1.837) : .... "Sesungguhnya kekasihku (Rasulullah) berwasiat kepadaku untuk selalu mendengar dan taat walaupun terhadap budak yang pesek hidungnya." .... ${ }^{17}$

3) Pemimpin dari kalangan perempuan

Kasus pemimpin di kalangan perempuan dapat dilihat dari kutipan ayat berikut:

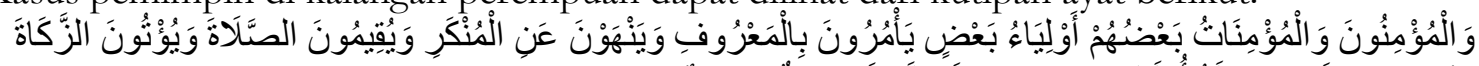

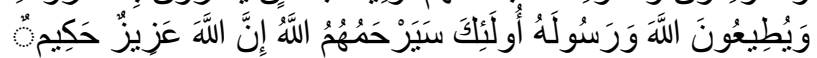

"Dan orang-orang yang beriman, lelaki dan perempuan, sebagian mereka menjadi penolong sebagian yang lain. Mereka menyuruh (mengerjakan) yang makruf, mencegah yang munkar, mendirikan shalat, menunaikan zakat dan mereka taat pada Allah dan Rasul-Nya. Mereka itu akan diberi rahmat oleh Allah; sesungguhnya Allah Maha Perkasa lagi Maha Bijaksana. (QS. Al-Taubah: 71).

Ayat tersebut menegaskan hubungan saling melengkapi antara perempuan dan lelaki, saling tolong menolong dan bersinergi untuk membangun msyarakat yang sejahtera. Menurut tafsir Kemenag RI, kebolehan wanita sebagai pemimpin dilihat dari bagaimana kekuatan perempuan dalam mengayomi yang lembut dan berwibawa. ${ }^{18}$

4) Pemimpin difabel

Disebutkan Ibn Ummi Maktum yang ditunjuk Nabi untuk menggantikan beliau di Madinah, padahal Ibn Ummi Maktum diketahui merupakan seorang yang buta. Kasus ini dapat dilihat dalam riwayat Abu Dawud no. 595 berikut:

\footnotetext{
${ }^{16}$ Hadis riwayat Muslim no. 1.840, Bab Wujub Tha'ah al-Umara' fi ghair al-Ma'shiyyah, "Kitab al-Imarah", Muslim bin al-Hajjaj Abu al-Hasan al-Qusyairi al-Naisaburi, Shabih Muslim, vol. 3 (Beirut: Dar Ihya' al-Turast al-'Arabi, Tt.), h. 1.469.

${ }^{17}$ Hadis riwayat Muslim no. 1.837, Bab Wujub Tha'ah al-Umara' fi ghair al-Ma'shiyyah, "Kitab al-Imarah", Muslim al-Naisaburi, Shabih Muslim, vol. 3, h. 1.467.

${ }^{18}$ Kementrian Agama Republik Indonesia, Kedudukan dan Peran Perempuan (Tafsir al-Qur'an Tematik), (Jakarta: Lajnah Pentashihan Mushaf al-Qur'an, 2009), h. 68-69.
} 
(Abu Dawud - 595) : ... telah menceritakan kepada kami Imran Al Qaththan dari Qatadah dari Anas bahwa Nabi shallallahu 'alaihi wasallam menunjuk Ibnu Ummi Maktum menggantikan beliau di Madinah dua kali. ${ }^{19}$

b. Ketentuan seorang pemimpin

1) Kriteria pemimpin

Tafsir Kementrian Agama RI menyebutkan kriteria seorang pemimpin, terutama pemimpin negara ialah sebagai berikut: beriman dan bertakwa; sehat jasmani dan rohani, jujur serta memiliki kemampuan; adil dan profesional; bertanggung jawab dan amanah; berani dan tegas; serta cinta kebenaran dan musyawarah. ${ }^{20}$ Salah satu hadis menunjukkan pemimpin (dalam konteks shalat) harus seorang yang memiliki latarbelakang pengetahuan yang luas, yakni:

(Nasa'i - 776) : .... "Tatkala Rasulullah Shallallahu'alaihi wasallam wafat. orang-orang Anshar berkata, "Dari kami ada pemimpin dan dari kalian (Muhajirin) juga ada pemimpin." Umar segera mendatangi mereka dan berkata, "Bukankah kalian tahu bahwa Rasulullah Shallallahu 'alaihi wasallam menyuruh Abu Bakar menjadi imam dalam shalat mereka? Siapa di antara kalian yang hatinya ingin mendahului Abu Bakar?" Mereka berkata, "Kami berlindung kepada Allah dari mendahului Abu Bakar."21

Ini menjelaskan bagaimana seorang pemimpin pun juga harus memiliki pengetahuan dan kemampuan serta profesionalitas yang kuat.

2) Larangan-larangan pemimpin

Di antara larangan terhadap pemimpin ialah menerima suap:

(Muslim - 1.833) : .... "Barangsiapa dari kalian yang aku angkat atas suatu amal, kemudian dia menyembunyikan dari kami (meskipun) sebuah jarum, atau sesuatu yang lebih kecil dari itu, maka itu adalah ghulul (pencurian) yang pada hari kiamat akan ia bawa." "Adi bin 'Amirah berkata, "Kemudian seorang laki-laki hitam dari Anshar -sepertinya saya pernah melihatnyaberdiri sambil berkata, "Wahai Rasulullah, kalau begitu saya akan tarik kembali tugas yang pernah anda bebankan kepada saya!" Beliau balik bertanya: "Ada apa denganmu?" dia menjawab, "Saya telah mendengar bahwa Anda pernah bersabda seperti ini dan seperti ini." Beliau bersabda: "Sekarang saya sampaikan, bahwa barangsiapa dari kalian yang aku tugasi atas suatu amal hendaklah ia datang baik dengan sedikit atau banyaknya, apa yang memang diberikan untuknya ia boleh mengambilnya, dan apa yang memang dilarang untuknya, maka ia harus dapat menahan diri.",22

Larangan kedua ialah menipu rakyat:

(Muslim - 142) : ... Ma'qil lalu berkata, "Sungguh saya akan menceritakan kepadamu suatu hadits yang pernah saya dengar langsung dari Rasulullah shallallahu 'alaihi wasallam, sekiranya saya masih hidup lama niscaya tidak akan saya ceritakan hal ini kepadamu. Sesungguhnya saya pernah mendengar Rasulullah shallallahu 'alaihi wasallam bersabda: "Tidaklah seorang pemimpin yang Allah serahi untuk memimpin rakyatnya, ketika meninggal dalam keadaan menipu rakyatnya, melainkan Allah akan mengharamkan surga untuknya." Dan telah menceritakan kepada kami Yahya bin Yahya telah mengabarkan kepada kami Yazid bin Zurai' dari Yunus dari Hasan dia berkata, 'Ibnu Ziyad menemui Ma'qil bin Yasar yang sedang sakit, seperti haditsnya Abu Al Asyhab, lalu ia menambahkan, "Ibnu Ziyad bertanya, "Tidakkah sebelumnya kamu telah menceritakan hal ini kepadaku?"

${ }^{19}$ Hadis riwayat Abu Dawud no. 595, "Kitab al-Shalah", Sulaiman bin al-Asy'at bin Syidad bin 'Amr alSajastani, Sunan Abu Dawnd, vol. 2 (Ttp: Mauqi' Wizarah al-Auqaf al-Mishriyyah, Tt.), h. 306.

${ }^{20}$ Tafsir Kementrian Agama RI, Al-Qur'an dan Kenegaraan (Tafsir al-Qur'an Tematik), (Jakarta: Lajnah Pentashihan Mushaf al-Qur'an, 2011), h. 191-207.

${ }^{21}$ Hadis riwayat al-Nasa'i no. 776, Abu 'Abd al-Rahman Ahmad bin Syu'aib al-Nasa'i, Sunan al-Nasa'i bi Syarh al-Suyuthi wa Hasyiyah al-Sanadi, vol. 2 (Beirut: Dar al-Ma’rifah, 1420 H), h. 409.

${ }^{22}$ Hadis riwayat Muslim no. 1.833, Bab Tahrim Hidaya al-'Amal, "Kitab al-Imarah", Muslim alNaisaburi, Shabih Muslim, vol. 3, h. 1.465. 
Dia menjawab, "Saya belim pernah menceritakan hal ini kepadamu atau belum pernah bercerita kepadamu." 23

Larangan ketiga, penguasa yang dzalim:

(Muslim - 1.830) : .... "Sesungguhnya seburuk-buruk penguasa adalah penguasa yang zhalim, maka janganlah kamu termasuk dari mereka." Lalu 'Ubaidullah berkata kepadanya, "Duduklah, kamu ini hanyalah sahabat Muhammad shallallahu 'alaihi wasallam yang masih yunior (rendahan)." Maka "Aidz pun ganti berkata, "Apakah di antara mereka ada yang disebut sebagai sahabat kelas yunior?" Sebenarnya yang pantas disebut sahabat kelas rendahan adalah orang-orang setelah mereka dan juga yang selain mereka." ${ }^{24}$

3) Pengangkatan pemimpin

Terdapat narasi yang cukup panjang tentang riwayat penunjukkan Umar untuk pengganti setelahnya, tetapi Umar mengurungkan niatnya, yakni:

(Muslim - 1.830) : .... Ibnu Umar dia berkata, "Aku pernah menemui Hafshah, lalu dia bertanya, "Apakah kamu tahu bahwa ayahmu tidak mau menunjuk seorang Khalifah?" Abdullah berkata, Lalu aku berkata, "Sepertinya dia tidak mau melakukan hal itu." Hafshah berkata, "Ia (Umar bin Khattab) harus melakukan hal itu." Lalu aku bersumpah untuk meyakinkan (Umar) akan hal itu, namun dia hanya terdiam sehingga aku merasa tidak ingin untuk membicarakannya lagi. Akan tetapi, aku merasa seakan-akan aku sedang memikul gunung di pundak kanan aku, hingga akhirnya aku menemuinya lagi. Umar bertanya kepadaku tentang keadaan manusia, maka aku pun menjawab seadanya. Lalu aku berkata kepadanya, "Aku mendengar masyarakat sedang membicarakan tentang sesuatu dan aku bersumpah untuk menyampaikan berita ini kepadamu, menurut pandangan mereka selama ini, kamu adalah seorang Khalifah yang tidak ingin menunjuk seorang Khalifah atau pengganti. Bagaimana pendapatmu sekiranya kamu seorang penggembala unta atau kambing, kemudian dia datang kepadamu dengan meninggalkan hewan gembalannya, maka bukankah kamu melihat bahwa ia telah menyia-nyiakannya? Terlebih lagi, gembala yang akan kamu atur itu adalah manusia." Abdullah berkata, "Ternyata Umar menyutujui pendapatku. Sejenak dia menundukkan kepalanya dan mengangkatnya kembali mengarah kepadaku serata berkata, "Sesungguhnya Allah Azza Wa Jalla akan menjaga agama-Nya, sekiranya saat ini aku tidak menunjuk seorang Khalifa, maka bukankah Rasulullah shallallahu 'alaihi wasallam sendiri sudah pernah melakukannya? Dan sekiranya nanti aku menunjuk seorang Khalifah penggantiku, maka bukankah hak itu juga pernah dilakukan oleh Abu Bakar?” Abdullah berkata, "Demi Allah, ketika dia menyinggung nama Rasulullah shallallahu 'alaihi wasallam dan Abu Bakar, maka sadarlah aku bahwa dia memang tidak bermaksud seperti Rasulullah shallallahu 'alaihi wasallam, bahwa dia tidak menunjuk secara langsung orang yang akan menggantikannya menjadi Khalifah." 25

c. Ketaatan terhadap pemimpin

Beberapa riwayat yang menyebutkan keharusan menaati perintah seorang pemimpin ialah:

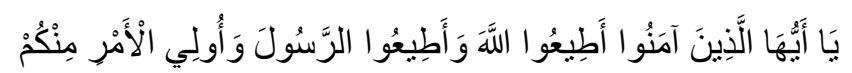

"Wahai orang-orang yang beriman, taatilah Allah dan Rasul-Nya dan Ulil amri di antara kamu ..." (QS. Al-Nisa: 59).

${ }^{23}$ Hadis riwayat Muslim no. 142, Bab Fadhilah al-Imam al-'Adil wa 'Uqubah al-Ja'ir, "Kitab al-Imarah", Muslim al-Naisaburi, Shabih Muslim, vol. 3, h. 1.459.

${ }^{24}$ Hadis riwayat Muslim no. 1.830, Bab Fadbilah al-Imam al-'Adil wa 'Uqubab al-Ja'ir, "Kitab al-Imarah", Muslim al-Naisaburi, Shabih Muslim, vol. 3, h. 1.461.

${ }^{25}$ Hadis riwayat Muslim no. 1.830, Bab al-Istikblaf wa Tarkubu, "Kitab al-Imarah", Muslim al-Naisaburi, Shabih Muslim, vol. 3, h. 1.454. 
(Muslim - 1.836) : .... "Wajib bagi kalian untuk mendengar dan taat baik dalam keadaan susah maupun senang, dalam perkara yang disukai dan dibenci dan biarpun merugikan kepentinganmu." 26

(Muslim - 1.836) : .... "Barang siapa keluar dari keta'atan dan memisahkan diri dari Jama'ah kemudian dia mati, maka matinya seperti mati jahiliyah. Barangsiapa terbunuh di bawah bendera kefanatikan, balas dendam karena kefanatikan, dan berperang karena kebangsaan, maka dia tidak termasuk dari ummatku. Dan barangsiapa keluar dari ummatku lalu (menyerang) ummatku dan membunuh orang yang baik maupun yang fajir, dan tidak memperdulikan orang mukminnya serta tidak pernah mengindahkan janji yang telah dibuatnya, maka dia tidak termasuk dari golonganku." ${ }^{27}$

Dalam beberapa riwayat menyebutkan keutamaan suku Quraisy dalam menjalankan roda pemerintahan, seperti dapat berlaku adil, menyayangi rakyat dan lain sebagainya. Akan tetapi, mereka juga memiliki konsekuensi jika melakukan pelanggaran terhadap amanah yang diberikan.

"Pemimpin itu dari suku Quraisy: jika mereka diminta untuk mengasihi mereka mengasihi, jika berjanji mereka menepati, dan jika menghakimi mereka mampu berbuat adil. Tetapi, jika mereka tidak melakukannya, maka mereka akan mendapat laknat Allah, para malaikat dan seluruh manusia."28

Dari riwayat tersebut dapat dilihat bahwa rasisme yang ditunjukkan pada hadis alBukhari no. 3.369 menjadi melebur dengan adanya riwayat di atas yang lebih menyodorkan akibat yang dihasilkan dari kepemimpinan seseorang. Terlihat bahwa audience riwayat di atas tidak hanya ditunjukkan pada suku Quraisy saja, tetapi pada masayarakat umum dan individu-individu yang jika diamanahi kepemimpinan ia tidak menjaga amanah tersebut dengan baik.

Beberapa hadis Nabi jelas menunjukkan sifat seorang pemimpin. Tidak terdapat narasi dari beberapa riwayat yang menjelaskan syarat utama seorang pemimpin dengan latar belakang budayanya. Adapun hadis-hadis yang memuat sifat seorang pemimpin tersebut ialah:

a. Tidak ambisius atau haus kekuasaan

(Bukhari - 6.727) : .... "Wahai Abdurrahman bin Samurah, Janganlah kamu meminta jabatan, sebab jika engkau diberi (jabatan) karena meminta, kamu akan ditelantarkan, dan jika kamu diberi dengan tidak meminta, kamu akan ditolong, dan jika kamu melakukan sumpah, kemudian kamu melihat suatu yang lebih baik, bayarlah kaffarat sumpahmu dan lakukanlah yang lebih baik." 29

b. Penyayang dan disayang rakyatnya

(Muslim - 1.855) : .... "Sebaik-baik pemimpin kalian adalah mereka mencintai kalian dan kalian mencintai mereka, mereka mendo'akan kalian dan kalian mendo'akan mereka. Dan sejelek-jelek pemimpin kalian adalah mereka yang membenci kalian dan kalian membenci mereka, mereka mengutuk kalian dan kalian mengutuk mereka." Beliau ditanya, "Wahai Rasulullah, tidakkah kita memerangi mereka?" maka beliau bersabda: "Tidak, selagi mereka mendirikan shalat bersama kalian. Jika kalian melihat dari pemimpin kalian sesuatu yang

${ }^{26}$ Hadis riwayat Muslim no. 1.836, Bab Wujub Tha'ah al-Umara' fi ghair M'shiyyah, "Kitab al-Imarah", Muslim al-Naisaburi, Shahih Muslim, vol. 3, h. 1.467.

${ }^{27}$ Hadis riwayat Muslim no. 1.836, Bab Wujub Mulazamah Jama'ah al-Muslimin 'ind Dzuhur al-Fitan wa fi Kulli Hal wa Tahrim, "Kitab al-Imarah", Muslim al-Naisaburi, Shabih Muslim, vol. 3, h. 1.476.

${ }^{28} \mathrm{Abu}$ Bakar al-Arabi, al-'Awashim min al-Qawashim (Saudi Arabia, wazarah al-syu'un al-Islamiyyah wa alauqaf wa al-Da'wah wa al-Irsyad, 1419 H), h. 70.

${ }^{29}$ Hadis riwayat al-Bukhari no. 6.727, Bab Man lam Yas'al al-Imarah A'anabullab 'alaiha, "Kitab alAhkam", Al-Bukhari, Al-Jami' ..., vol. 6, h. 2.613. 
tidak baik maka bencilah tindakannya, dan janganlah kalian melepas dari ketaatan kepada mereka." ${ }^{30}$

c. Menjalankan amanah

(Bukhari - 6.731) : .... "Tidaklah seorang hamba yang Allah beri amanat kepemimpinan, namun dia tidak menindaklanjutinya dengan baik, selain tak bakalan mendapat bau surga." ${ }^{31}$

d. Bertanggung jawab

(Muslim - 1.829) : .... "Ketahuilah, setiap kalian adalah pemimpin, dan setiap kalian bertanggung jawab atas apa yang dipimpinnya. Seorang pemimpin yang memimpin manusia akan bertanggung jawab atas rakyatnya, seorang laki-laki adalah pemimpin atas keluarganya, dan dia bertanggung jawab atas mereka semua, seorang wanita juga pemimpin atas rumah suaminya dan anak-anaknya, dan dia bertanggung jawab atas mereka semua, seorang budak adalah pemimpin atas harta tuannya, dan dia bertanggung jawab atas harta tersebut. Setiap kalian adalah pemimpin dan akan bertanggung jawab atas kepemimpinannya."32

e. Berlaku adil

(Muslim - 1.827) : .... "Orang-orang yang berlaku adil berada di sisi Allah di atas mimbar (panggung) yang terbuat dari cahaya, di sebelah kanan Ar Rahman 'azza wajalla -sedangkan kedua tangan Allah adalah kanan semua-, yaitu orang-orang yang berlaku adil dalam hukum, adil dalam keluarga dan adil dalam melaksanakan tugas yang di bebankan kepada mereka." ${ }^{33}$

\section{Ide Dasar}

Beberapa hal yang perlu dipertimbangkan terkait hadis di atas ialah

a. Teks al-Qur'an dan hadis tidak dapat dipahami secara tekstual, yaitu seorang pemimpin harus berasal dari suku tertetu.

b. Terdapat syarat-syarat tertentu untuk menjadi seorang pemimpin, terutama berdasarkan kualitas.

Oleh karena itu, ide dasar yang dapat dipetik dari berbagai teks al-Qur'an dan hadis di atas ialah ukuran seorang pemimpin tidak dapat ditentukan oleh latarbelakang sosial, ekonomi dan budayanya, tetapi lebih dilihat dari "kualitas kepemimpinan dan tanggung jawab sebagai pemimpin".

\section{Kontekstualitas}

Kasus rasisme yang terjadi belakangan merupakan rasisme yang muncul kembali yang disebabkan adanya kepentingan politik. Pada kenyataannya, kasus rasisme yang terkait isu ekonomi dan sosial telah banyak yang hampir surut. Menurut penelitian ISEAS, kasus diskriminsi ras China dan ras pribumi telah melebur sejak adanya kerjasama antara orangorang China dan Indonesia. Bahkan dalam hal ini, orang-orang China Indonesia dapat berpotensi menjembatani kultur dan komersial yang ada. ${ }^{34}$ Di Lasem (salah satu daerah di Jawa) misalnya, harmonisasi terjadi dalam kerukunan antar etnis dan pemeluk agama. Kerukunan tersebut tergambar dalam adanya perkawinan silang dan perasaan bersaudara antarwarga. ${ }^{35}$

${ }^{30}$ Hadis riwayat Muslim no. 1.855, Bab Khiyar al-A'immah Syararibim, "Kitab al-Imarah”, Muslim alNaisaburi, Shabih Muslim, vol. 3, h. 1.481.

${ }^{31}$ Hadis riwayat al-Bukhari no. 6.731, Bab Man Istar'a Ri'ayatan fa lam Yanshah, "Kitab al-Ahkam", AlBukhari, Al-Jami'..., vol. 6, h. 2.614.

${ }^{32}$ Hadis riwayat Muslim no. 1.829, Bab Fadhilah al-Imam al-'Adil wa 'Uqubab al-Ja'ir, "Kitab al-Imarah", Muslim al-Naisaburi, Shabih Muslim, vol. 3, h. 1.459.

${ }^{33}$ Hadis riwayat Muslim no. 1.827, Bab Fadhilah al-Imam al-'Adil wa 'Uqubab al-Ja'ir, "Kitab al-Imarah", Muslim al-Naisaburi, Shabih Muslim, vol. 3, h. 1.458.

${ }^{34}$ Charlotte Setijadi, "Ethnic Chinese in Contemporary Indonesia: Changing Identity Politics and the Paradox of Sinification” dalam ISEAS Yusof Ishak Institute, no. 12, 2016, hlm. 1-2. Lihat juga Weiqing Song, "Securitization of The "China Threat" Discourse; A Poststructuralist Account" dalam China Review, Vol. 15, No. 1, 2015, h. 164-165.

${ }^{35}$ Ahmad Atabik, "Harmonisasi Kerukunan Antar Etnis dan Penganut Agama di Lasem" dalam Fikrab; Jurnal Ilmu Aqidah dan Studi Keagamaan, Vol. 4, No. 1, 2016, h. 47-48. 
Diskriminasi ras China juga dapat melebur dengan adanya kebijakan-kebijakan yang dibuat pemerintah, sebagaimana kebijakan yang dibuat pada masa rezim Abdurrahman Wahid "Gus Dur". Kebijakan tersebut tergambar dengan adanya kebebasan kaum minoritas ras China yang berkeyakinan Konghucu dan perayaan hari raya imlek. ${ }^{36}$ Selain itu, kebijakan lain yang dilakukan oleh para aktivis hak asasi manusia (Organisasi PITI Korwil DIY) yang melakukan pembauran dalam beberapa dekade kepemimpinannya, merupakan sebuah upaya untuk melakukan integrasi dan harmonisasi sosial. Mereka menggunakan pendekatan agama dengan melalui media dakwah, sosial yang dilakukan dengan menghimbau anggota untuk berinteraksi yang baik dengan lingkungan sekitarnya, pendekatan budaya dengan memperkenalkan budaya Tionghoa kepada masayarakat dan politik dengan terjun langsung pada politik praktis. ${ }^{37}$

Namun, kasus yang terjadi pada calon kepala daerah Jakarta, Ahok, juga yang terjadi pada presiden Jokowi merupakan kasus yang terkait masalah politik. Di mana, dalam proses pemilihan kepala daerah tersebut melibatkan banyak partai politik. Ahok misalnya, jelas memiliki lawan politik di sisi lainnya. Berita tentang penistaan agama merupakan salah satu penyulut gagalnya ahok naik dan mendapatkan suara kembali sebagai kepala daerah. Perlu disadari juga bahwa kemunculan kasus tersebut bertepatan sebelum pemilihan kepala daerah setempat. Jika ditelisik lebih jauh, tentu ada peran ideologi politik yang kuat di dalamnya. Kasus black campaign (kampanye hitam) misalnya, bukan tidak mungkin masuk dalam ruang ini. Dalam kasus Ahok, ada dua pihak yang merasa diuntungkan. Pertama, para pelaku black campaign. Yang tidak mungkin tidak meraup keuntungan dari kasus ini. Kedua, golongan kaum radikal yang berperan cukup aktif dan terlibat lebih jauh dalam kasus tersebut.

Para pelaku black campaign, melakukan aksi penyebaran brosur yang mendiskreditkan para calon-calon kepala daerah. Mereka tentu diuntungkan dengan hal ini. Mereka menyebarkan berita-berita negatif tentang calon kepala daerah. ${ }^{38}$ Di sisi lain, peristiwa 212 yang terjadi belakangan merupakan kasus yang dilangsir oleh adanya dugaan penistaan agama yang dilakukan oleh Basuki Tjahaja Purnama, Ahok. Pada peristiwa tersebut banyak tokoh yang terlibat, seperti Rizieq Shihab, yang merupakan pimpinan Front Pembela Islam (FPI). Kehadiran tokoh tersebut berdampak adanya banyak dukungan dari berbagai kalangan dan atmosfir masyarakat, terutama para kaum radikalis di seluruh Indonesia. Hal ini terlihat kemudian saat para peserta peristiwa 212 tersebut melakukan reuni di lapangan Monumen Nasional (Monas), Jakarta Pusat. ${ }^{39}$

Menurut direktur Lembaga Bantuan Hukum (LBH) Jakarta, Algiffari Aqsa menyebutkan bahwa Ahok telah menjadi korban penggunaan pasal anti-demokrasi, yaitu Pasal 156a KUHP tentang penodaan agama. ${ }^{40}$ Aksi bela Ahok juga dilakukan oleh Sahiron Syamsuddin dengan memberikan penafsiran ulang terhadap surah al-Maidah ayat 51 tersebut. Menurut Syamsuddin, kata auliya' yang dipermasalahkan, secara literal berarti penolong-penolong dan teman-teman setia, yang jika dilihat dari sisi historisnya bukan dalam konteks pertemanan dalam situasi damai, apalagi pemilihan kepala pemerintahan. Secara historis ayat tersebut turun dalam konteks peperangan, yang harus memerhatikan

${ }^{36}$ Ali Mustajab, "Kebijakan Politik Gus Dur terhadap China Tionghoa di Indonesia” dalam In Right; Jurnal Agama dan Hak Azazi Manusia, Vol. 5, No. 1, 2015, h. 189.

${ }^{37}$ Fahmi Rafika Perdana, "Integrasi Sosial Muslim-Tionghoa; Studi atas Partisipasi PITI DIY dalam Gerakan Pembauran” dalam Jurnal Ilmiah Sosiologi Agama, Vol. 9, No. 2, 2015, h. 117.

${ }^{38}$ Lani Diana, "Panwaslu DKI Temukan Selebaran Diduga Kampanye Hitam" diakses tanggal 5 Januari 2018 dalam https://pilkada.tempo.co

${ }^{39}$ Fachrur Rozie, "Reuni Aksi 212, dari Siapa Dana Rp 4 M?” diakses pada tanggal 5 Januari 2018 dalam http://news.liputan6.com

${ }^{40}$ Anugerah Perkasa, "Soal Penistaan Agama; LBH Jakarta 'Aksi Bela' Ahok” diakses tanggal 5 Januari 2018 dalam https://www.cnnindonesia.com 
strategi perang dan tidak boleh memihak atau menerima bantuan dari pihak-pihak lain yang tidak jelas komitmennya. ${ }^{41}$

Ini jelas mengilustrasikan bagaimana sistem penegakkan hukum di Indonesia. Kasus rasisme yang digandeng oleh ideologi kelompok-kelompok tertentu. Para penggiat politik mengambil keuntungan dengan kasus yang dialami oleh lawan politiknya. Di sisi lain, kelompok agama yang berpikir radikal justeru mempertahakan ideologinya yang dianggap dinistakan. Kelompok kecil lainnya pun masih merasakan kekhawatiran terhadap ras China yang mulai berperan dalam ruang politik di Indonesia. Hal ini dapat disimpulkan bahwa kasus diskriminasi ras China yang dialami Ahok merupakan kasus yang ditunggangi oleh kepentingan-kepentingan kelompok tertentu. Yang kemudian bersatu pada satu tujuan, yang pada akhirnya justeru mengombang-ambingkan persatuan dan perdamaian di Indonesia.

\section{Simpulan}

Kasus rasisme yang terjadi di Indonesia merupakan kasus lama yang hampir surut, namun kembali mencuat seiring dengan arus politik yang terus berkembang. Rasisme yang terjadi ialah adanya pengungkitan ras China yang kembali muncul pada kancah publik politik.

Kajian ini, yang melihat kembali bagaimana konteks rasisme politik pada masa Nabi, didapat beberapa hadis yang diriwayatkan oleh al-Bukhari, Muslim, Ahmad dan al-Darimi. Hadis-hadis tersebut merupakan hadis yang marfu', muttashil dan diriwayatkan oleh periwayat yang tsiqah. Hadis-hadis tersebut tidak dapat dipahami secara tekstual. Ide dasar yang dapat dipetik dari beberapa teks-teks baik itu teks hadis utama maupun teks-teks yang pendukung yang mengitarinya ialah bahwa seorang calon pemimpin dipilih karena kualitas, kemampuan dan dedikasinya, serta tanggung jawabnya, bukan dari segi kuantitas yang mendukungnya.

Kasus rasisme yang dialami Ahok merupakan kasus yang dipelopori oleh kelompokkelompok tertentu, seperti para pelaku politik dan kelompok radikal. Yang akhirnya bergandengan dan bersatu untuk menjatuhkan kelompok lainnya.

\section{Daftar Pustaka}

'Asyur, Ibn. Al-Tahrir wa al-Tanwir. Mauqi' al-Tafassir. Jilid 9. Tt.

Arabi, Abu Bakar al-. Al-'Awashim min al-Qawashim. Saudi Arabia: wazarah al-syu'un alIslamiyyah wa al-auqaf wa al-Da'wah wa al-Irsyad. $1419 \mathrm{H}$.

Asqalani, Ibn Hajar al-. Fath al-Bari Syarh Shabih al-Bukhari. Beirut: Dar al-Ma'rifah. Jilid 6. $1379 \mathrm{H}$.

Atabik, Ahmad. "Harmonisasi Kerukunan Antar Etnis dan Penganut Agama di Lasem" dalam Fikerab; Jurnal Ilmu Aqidah dan Studi Keagamaan. Vol. 4. No. 1. 2016.

Bukhari, Muhammad bin Ismail Abu 'Abdillah al-. Al-Jami' al-Shahih al-Mukhtashar. Beirut: Dar Ibn Katsir. 1987

Darimi, 'Abdullah bin 'Abd al-Rahman bin al-Fadhl bin Bahram al-. Sunan al-Darimi. Ttp: Mauqi' Wizarah al-Auqaf al-Mishriyyah. Tt.

Diana, Lani. "Panwaslu DKI Temukan Selebaran Diduga Kampanye Hitam" diakses tanggal 5 Januari 2018 dalam https://pilkada.tempo.co

Fadil, Iqbal. "4 Pengakuan JASMEV, pasukan Jokowi di media sosial" diakses tanggal 1 Januari 2018 dalam https://www.merdeka.com

Katsir, Ibn. Tafsir al-Qur'an al-'Adrim. Beirut: Dar Thaibah li al-Nasyr wa al-Tauzi'. Jilid 7. 1999.

Kementrian Agama Republik Indonesia. Al-Qur'an dan Kenegaraan (Tafsir al-Qur'an Tematik). Jakarta: Lajnah Pentashihan Mushaf al-Qur'an. 2011. 
Kementrian Agama Republik Indonesia. Kedudukan dan Peran Perempuan (Tafsir al-Qur'an Tematik). Jakarta: Lajnah Pentashihan Mushaf al-Qur'an. 2009.

Mustajab, Ali. "Kebijakan Politik Gus Dur terhadap China Tionghoa di Indonesia" dalam In Right; Jurnal Agama dan Hak. Azazi Manusia. Vol. 5. No. 1. 2015.

Naisaburi, Muslim bin al-Hajjaj Abu al-Hasan al-Qusyairi al-. Shabih Muslim. Beirut: Dar Ihya' al-Turast al-'Arabi. Tt.

Nasa'i, Abu 'Abd al-Rahman Ahmad bin Syu'aib al-. Sunan al-Nasa'i bi Syarh al-Suyuthi wa Hasyiyah al-Sanadi. Beirut: Dar al-Ma'rifah. $1420 \mathrm{H}$.

Perdana, Fahmi Rafika. "Integrasi Sosial Muslim-Tionghoa; Studi atas Partisipasi PITI DIY dalam Gerakan Pembauran” dalam Jurnal Ilmiah Sosiologi Agama. Vol. 9. No. 2. 2015.

Perkasa, Anugerah. "Soal Penistaan Agama; LBH Jakarta 'Aksi Bela' Ahok" diakses tanggal 5 Januari 2018 dalam https://www.cnnindonesia.com

Rozie, Fachrur. "Reuni Aksi 212, dari Siapa Dana Rp 4 M?" diakses pada tanggal 5 Januari 2018 dalam http://news.liputan6.com

Safari dan Akbar, "Kasus Ahok: Pertempuran China Pro Jokowi dan Amerika Pro SBY" diakses tanggal 1 Januari 2018 dalam http:// nasional.harianterbit.com

Sajastani, Sulaiman bin al-Asy'at bin Syidad bin 'Amr al-. Sunan Abu Dawud. Ttp: Mauqi' Wizarah al-Auqaf al-Mishriyyah. Tt.

Setijadi, Charlotte. "Ethnic Chinese in Contemporary Indonesia: Changing Identity Politics and the Paradox of Sinification" dalam ISEAS Yusof Ishak Institute. no. 12. 2016.

Song, Weiqing. "Securitization of The "China Threat" Discourse; A Poststructuralist Account" dalam China Review. Vol. 15. No. 1. 2015.

Suryadinata, Leo."Anti-China campaign in Jokowi's Indonesia" diakses tanggal 1 Januari 2018 dalam http://www.straitstimes.com

Syaibani, Abu 'Abdillah Ahmad bin Muhammad bin Hanbal bin Hilal bin Asad al-. Musnad Ahmad. Ttp: Mauqi' Wizarah al-Auqaf al-Mishriyyah. Tt.

Syamsuddin, Sahiron. Hermeneutika dan Pengembangan Ulumul Qur'an. Yogyakarta: Pesantren Nawesea Press. 2017. 